\title{
Metabolic flux in cellulose batch and cellulose- fed continuous cultures of Clostridium cellulolyticum in response to acidic environment
}

\author{
Mickaël Desvaux, Emmanuel Guedon and Henri Petitdemange
}

Laboratoire de Biochimie des Bactéries Gram +, Domaine Scientifique Victor Grignard, Université Henri Poincaré, Faculté des Sciences, BP 239, 54506 Vandœuvre-lès-Nancy Cédex, France

Author for correspondence: Henri Petitdemange. Tel: +33 3839120 53. Fax: +33 383912550. e-mail: hpetitde@lcb.uhp-nancy.fr

Clostridium cellulolyticum, a nonruminal cellulolytic mesophilic bacterium, was grown in batch and continuous cultures on cellulose using a chemically defined medium. In batch culture with unregulated pH, less cellulose degradation and higher accumulation of soluble glucides were obtained compared to a culture with the $\mathrm{pH}$ controlled at $\mathbf{7 \cdot 2}$. The gain in cellulose degradation achieved with pH control was offset by catabolite production rather than soluble sugar accumulation. The pH-controlled condition improved biomass, ethanol and acetate production, whereas maximum lactate and extracellular pyruvate concentrations were lower than in the non-pH-controlled condition. In a cellulose-fed chemostat at constant dilution rate and $\mathrm{pH}$ values ranging from 7.4 to $6 \cdot 2$, maximum cell density was obtained at pH 7.0. Environmental acidification chiefly influenced biomass formation, since at pH 6.4 the dry weight of cells was more than fourfold lower compared to that at pH 7.0, whereas the specific rate of cellulose assimilation decreased only from 11.74 to 10.13 milliequivalents of carbon (g cells) ${ }^{-1} \mathrm{~h}^{-1}$. The molar growth yield and the energetic growth yield did not decline as $\mathrm{pH}$ was lowered, and an abrupt transition to washout was observed. Decreasing the $\mathrm{pH}$ induced a shift from an acetate-ethanol fermentation to a lactate-ethanol fermentation. The acetate/ethanol ratio decreased as the $\mathrm{pH}$ declined, reaching close to 1 at $\mathrm{pH}$ 6.4. Whatever the $\mathrm{pH}$ conditions, lactate dehydrogenase was always greatly in excess. As pH decreased, both the biosynthesis and the catabolic efficiency of the pyruvate-ferredoxin oxidoreductase declined, as indicated by the ratio of the specific enzyme activity to the specific metabolic rate, which fell from $9 \cdot 8$ to 1.8. Thus a change of only $1 \mathrm{pH}$ unit induced considerable metabolic change and ended by washout at around pH 6.2. C. cellulolyticum appeared to be similar to rumen cellulolytic bacteria in its sensitivity to acidic conditions. Apparently, the cellulolytic anaerobes studied thus far do not thrive when the pH drops below 6.0, suggesting that they evolved in environments where acid tolerance was not required for successful competition with other microbes.

Keywords: cellulolytic bacteria, flux analysis, environmental $\mathrm{pH}$, cellulose degradation, chemostat

\section{INTRODUCTION}

Biological degradation of cellulosic materials is signifi-

Abbreviations: $A A D H$, acetaldehyde dehydrogenase; $A K$, acetate kinase $\mathrm{ADH}$, alcohol dehydrogenase; ATP-Eff, efficiency of ATP generation; $\mathrm{Fd}$, ferredoxin; G1P, glucose 1-phosphate; G6P, glucose 6-phosphate; LDH, lactate dehydrogenase; meq C, milliequivalent of carbon; PFO, pyruvateferredoxin oxidoreductase; PTA, phosphotransacetylase; $R$, ratio of specific enzyme activity to metabolic flux. cant in swamps, marshes, sediments, composts and anaerobic waste treatment, and in the intestinal tracts of herbivorous animals and insects (Ljungdahl \& Eriksson, 1985). Within the biosphere, cellulolytic clostridia participate significantly in this process (Bayer \& Lamed, 1992; Leschine, 1995; Tomme et al., 1995), which is strongly linked to the global carbon cycle (Wolin \& Miller, 1987).

High concentrations of fermentation acids and, as a 
result, low $\mathrm{pH}$ conditions are often found in anaerobic habitats (Ljungdahl \& Eriksson, 1985; Goodwin \& Zeikus, 1987). Yet due to their particular pattern of intracellular $\mathrm{pH}$ regulation (Huang et al., 1985) compared with other low-G + C Gram-positive anaerobes, mainly the so-called lactic acid bacteria, the clostridialtype bacteria are generally considered as restricted to less acidic ecological niches (Russell et al., 1996).

Cellulolytic clostridia digest cellulose through extracellular multienzyme complexes (Béguin \& Lemaire, 1996; Bayer et al., 1998). These cellulosomes are found at the surface of the bacteria and allow both cell adhesion to cellulose fibres (Bayer et al., 1996) and very efficient degradative activity against crystalline cellulose due to a high synergism of the different cellulase components (Boisset et al., 1999).

Clostridium cellulolyticum is a low-G + C Gram-positive nonruminal cellulolytic mesophilic bacterium belonging to the clostridial group III, and also classified in family 4, genus 2, of a new proposed hierarchical structure for clostridia (Collins et al., 1994). Using cellobiose, a soluble substrate, several advances in understanding of the metabolism of this bacterium have been made, such as (i) a better control of catabolism in a mineral salt-based medium (Payot et al., 1998; Guedon et al., 1999b), (ii) recognition of major differences in regulatory responses in cellobiose-limited and cellobiose-saturated chemostat cultures (Guedon et al., 2000b), and (iii) the importance of glucose 6-phosphate (G6P) and glucose 1-phosphate (G1P) nodes in regulation of metabolic fluxes (Guedon et al., 2000a). Earlier investigations using cellulose have been mainly devoted to cellulolytic performance and bacterial behaviour towards insoluble substrates (Giallo et al., 1985; Gelhaye et al., 1993a, b). A few studies, however, have focused on the metabolism of this bacterium on cellulose: recent investigation of cellulose fermentation performed in batch culture (Desvaux et al., 2000) indicated (i) variation of metabolite yields as a function of initial cellulose concentration, and (ii) an early growth inhibition related to pyruvate overflow as with cellobiose (Guedon et al., 1999a). A study in a celluloselimited chemostat indicated that bacterial metabolism was not as distorted as with cellobiose and C. cellulolyticum appeared well adapted to a cellulolytic lifestyle (Desvaux et al., 2001).

Whereas the effects of acidic conditions on the growth of cellulolytic rumen bacteria have been the subject of considerable research (Russell \& Dombrowski, 1980; Kalachniuk et al., 1994; Russell \& Wilson, 1996; Russell \& Diez-Gonzalez, 1998), little is known of how these conditions affect the metabolism of cellulolytic clostridia (Duong et al., 1983; Mitchell, 1998). The aim of the present work was to investigate the cellulose degradation and metabolic changes of C. cellulolyticum on insoluble cellulose caused by environmental $\mathrm{pH}$ conditions. Since conditions in natural environments most likely resemble those somewhere between a closed batch culture and an open continuous culture system (Kovárová-Kovar \& Egli, 1998), both types of culture systems were used to study the effects of $\mathrm{pH}$ on growth and metabolism of C. cellulolyticum.

\section{METHODS}

Organism and medium. Clostridium cellulolyticum ATCC 35319 was isolated from decayed grass by Petitdemange $e t$ al. (1984). Germination of stocks of spores and anaerobic cell culture were performed as described by Desvaux et al. (2000). The defined medium used in all experiments was a modified CM3 medium as described by Guedon et al. (1999a) containing various amounts of cellulose MN301 (Macherey-Nagel) as specified in Results.

Growth conditions. Clostridium cellulolyticum was grown either in batch or in continuous culture with cellulose as sole carbon and energy source. All experiments were performed in a 1.51 working volume fermenter (LSL Biolafitte) as previously described (Guedon et al., 1999a, b); the temperature was maintained at $34^{\circ} \mathrm{C}$ and the $\mathrm{pH}$ was controlled by automatic addition of $3 \mathrm{M} \mathrm{NaOH}$ or $1 \mathrm{M} \mathrm{HCl}$ as specified in Results. The inoculum was $10 \%(\mathrm{v} / \mathrm{v})$ from an exponentially growing culture.

Batch cultures were prepared as previously described (Desvaux et al., 2000). The chemostat system used was a segmented gas-liquid continuous culture device as described by Weimer et al. (1991b) with some modifications (Desvaux et al., 2001). The cultures were maintained for a period of eight to nine residence times (Desvaux et al., 2001); for each condition the data were the mean of at least three samples.

Analytical procedures. Biomass, cellulose concentration, gases, extracellular proteins, amino acids, glucose, soluble cellodextrins, glycogen, acetate, ethanol and lactate extracellular pyruvate were assayed as described by Desvaux et al. (2001). Pyridine nucleotides, coenzyme A (CoA), acetyl-CoA, G1P and G6P were extracted and fluorimetric determination performed as previously described (Desvaux et al., 2001). ATP and ADP were measured using the luciferin-luciferase luminescence system (Microbial Biomass Test Kit, Celsis Lumac) (Guedon et al., 2000a).

Enzyme assays. Cell extracts were prepared and enzyme assays performed as previously described (Guedon et al., 2000a). Pyruvate-ferredoxin (Fd) oxidoreductase (PFO) (EC 1.2.7.1), lactate dehydrogenase (LDH) (EC 1.1.1.27), phosphotransacetylase (PTA) (EC 2.3.1.8), acetate kinase (AK) (EC 2.7.2.1), acetaldehyde dehydrogenase (AADH) (EC 1.2.1.10) and alcohol dehydrogenase (ADH) (EC 1.1.1.1) were assayed as described by Desvaux et al. (2001). Calculations and carbon flux analysis. The metabolic pathways and equations of cellulose fermentation by C. cellulolyticum, expressed as $n$ hexose equivalents (hexose eq) corresponding to $n$ glucose residues of the cellulose chain, were previously reported (Desvaux et al., 2000).

The $q_{\text {cellulose }}$ is the specific rate of hexose residue fermented in mmol (g cells $)^{-1} \mathrm{~h}^{-1} \cdot q_{\text {acetate }}, q_{\text {ethanol }}$ and $q_{\text {lactate }}$ are the specific rates of product formation in mmol $(\mathrm{g} \text { cells })^{-1} \mathrm{~h}^{-1}$. $q_{\text {extracellular pyruvate }}$ is the specific rate of extracellular pyruvate formation in $\mu \mathrm{mol}(\mathrm{g} \text { cells })^{-1} \mathrm{~h}^{-1}$. $q_{\mathrm{NADH}}$ produced and $q_{\text {NADHconsumed }}$ are the specific rates of NADH production and NADH consumption respectively in $\mathrm{mmol}(\mathrm{g} \text { cells })^{-1} \mathrm{~h}^{-1}$ and were calculated as follows: $q_{\mathrm{NADH} \text { produced }}=q_{\text {pyruvate }}$ and $q_{\text {NADH consumed }}=2 q_{\text {ethanol }}+q_{\text {lactate }}$. The specific rate of acid production (O'Sullivan \& Condon, 1999), was calculated as follows: $q_{\mathrm{H}^{+}}=q_{\text {acetate }}+q_{\text {lactate }}+q_{\text {extracellular pyruvate }}$.

The molar growth yield $\left(Y_{\mathrm{x} / \mathrm{s}}\right)$ is expressed in g cells (mol hexose eq fermented $)^{-1}$. The energetic yield of biomass $\left(Y_{\text {АтP }}\right)$ 


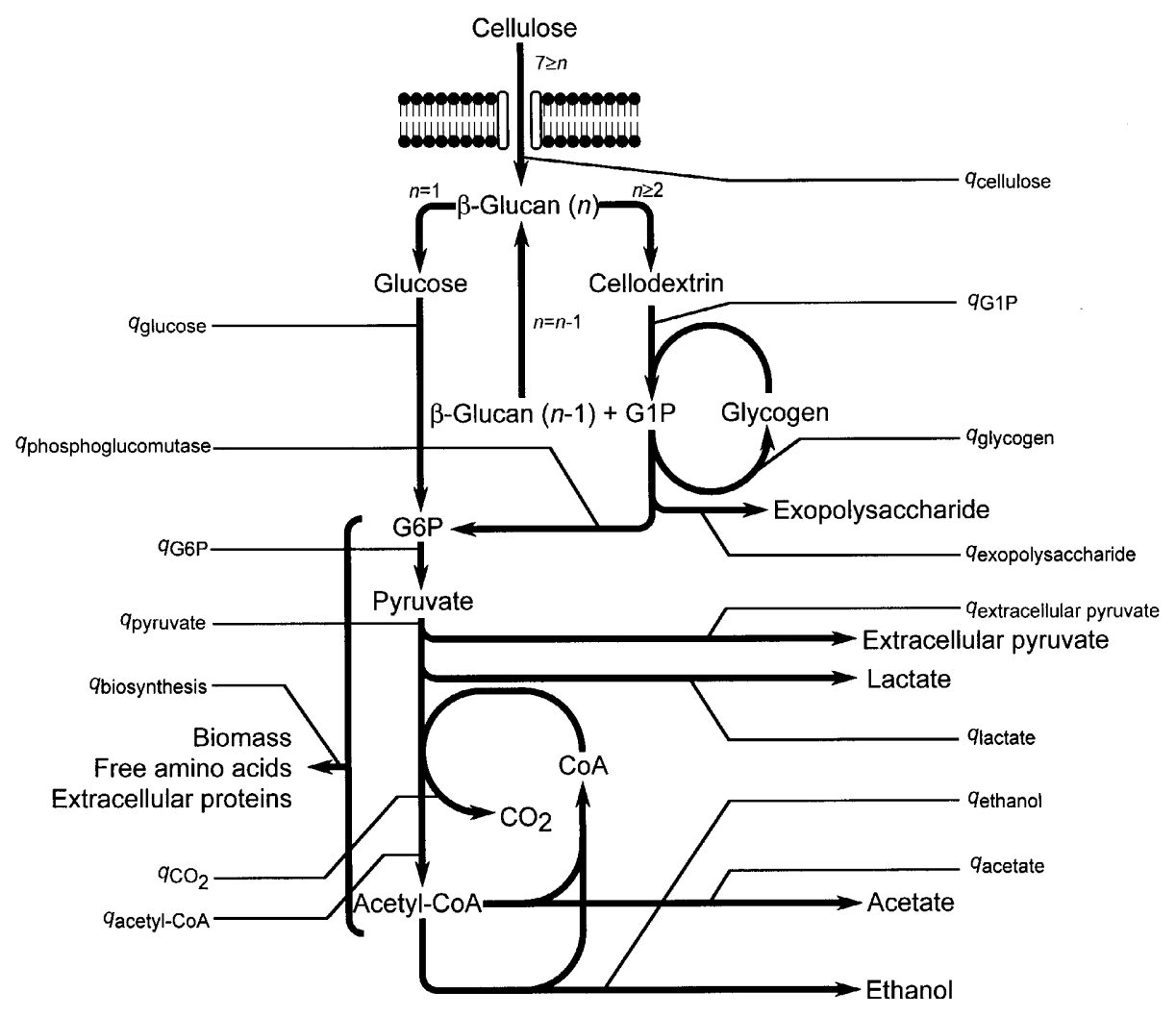

Fig. 1. Carbon flux distribution within the central metabolic pathways of $C$. cellulolyticum when grown on cellulosic substrate ( $n$ is the number of hexose residues inside the biopolymer). Carbon flow corresponds to the equations given in Methods.

was (Desvaux et al., 2000): $Y_{\mathrm{ATP}}=\operatorname{concn}_{\text {biomass }} /(1.94$ concn $_{\text {acetate }}+0.94$ concn $_{\text {ethanol }}+0.94$ concn $_{\text {lactate }}+0.94$ concn $_{\text {extracellular pyruvate }}$ ). $Y_{\text {ATP }}$ is expressed in g cells (mole ATP produced $)^{-1} \cdot q_{\mathrm{ATP}}$ is the specific rate of ATP generation in mmol (g cells $)^{-1} \mathrm{~h}^{-1}$, calculated by the following equation (Desvaux et al., 2000): $q_{\mathrm{ATP}}=1.94 q_{\text {acetate }}+0.94 q_{\text {ethanol }}+$ $0.94 q_{\text {lactate }}+0.94 q_{\text {extracellular pyruvate }}$. The energetic efficiency (ATP-Eff) corresponding to the ATP generation in cellulose catabolism is given by the ratio of $q_{\mathrm{ATP}}$ to $q_{\text {cellulose }}$ (Miyagi et al., 1994).

Distribution of the carbon flow by stoichiometric flux analysis (Papoutsakis, 1984; Desai et al., 1999a, b) was determined by adapting the model developed by Holms (1996) to $C$. cellulolyticum metabolism (Desvaux et al., 2001).

At steady state, the carbon flux through each enzyme of the known metabolic pathway, as indicated in Fig. 1, was calculated in milliequivalents of carbon (meq C) (g cells $)^{-1} \mathrm{~h}^{-1}$, as follows :

$$
\begin{aligned}
& q_{\mathrm{G} 1 \mathrm{P}}=0.63 q_{\text {cellulose }} \\
& q_{\mathrm{glucose}}=0.37 q_{\text {cellulose }} \\
& q_{\text {biosynthesis }}=q_{\text {biomass }}-q_{\mathrm{glycogen}}+q_{\text {amino acid }}+q_{\text {extracellular protein }} \\
& q_{\mathrm{G} 6 \mathrm{P}}=q_{\text {biosynthesis }}+q_{\text {pyruvate }} \\
& q_{\text {phosphoglucomutase }}=q_{\mathrm{G} 6 \mathrm{P}}-q_{\text {glucose }} \\
& q_{\text {exopolysaccharide }}=q_{\mathrm{G} 1 \mathrm{P}}-q_{\text {phosphoglucomutase }}-q_{\mathrm{glycogen}} \\
& q_{\text {acetyl-CoA }}=q_{\text {acetate }}+q_{\text {ethanol }} \\
& q_{\text {carbon dioxide }}=\left(q_{\text {acetate }}+q_{\text {ethanol }}\right) / 2
\end{aligned}
$$

$q_{\text {pyruvate }}=$

$q_{\text {acetate }}+q_{\text {ethanol }}+q_{\text {lactate }}+q_{\text {extracellular pyruvate }}+q_{\text {carbon dioxide }}$

The turnover of a pool $\left(\mathrm{h}^{-1}\right)$ was calculated from specific rate and pool size expressed in moles or in carbon equivalents (Holms, 1996). The ratio $R$ corresponded to the ratio of specific enzyme activity to metabolic flux (Holms, 1996; Desvaux et al., 2001).

\section{RESULTS}

\section{Kinetic profile in batch cellulose fermentation}

C. cellulolyticum was grown in a bioreactor on defined medium with $6.7 \mathrm{~g}$ cellulose $\mathrm{l}^{-1}$ under non-pH-controlled and pH-controlled conditions (Fig. 2). In the non-pH-controlled run, the $\mathrm{pH}$ dropped to $5 \cdot 3$ after $6 \mathrm{~d}$ culture (Fig. 2Ia). Compared to the batch culture controlled at $\mathrm{pH} 7 \cdot 2$, the final biomass attained in the non-pH-controlled condition was lower, as was the percentage of cellulose degradation, which reached $67 \%$, as against $86 \%$ in the $\mathrm{pH}$-controlled fermentation (Figs $2 \mathrm{Ib}$ and $2 \mathrm{IIb}$ ). The maximum specific growth rate, however, was similar in non-pH-controlled and $\mathrm{pH}$ controlled batch culture, i.e. 0.053 and $0.056 \mathrm{~h}^{-1}$ respectively.

The metabolite production profiles were clearly different in the two fermentation modes (Fig. 2Ic and 2IIc). With $\mathrm{pH}$ regulation, higher final levels of acetate and ethanol were reached, whereas the lactate and extracellular 

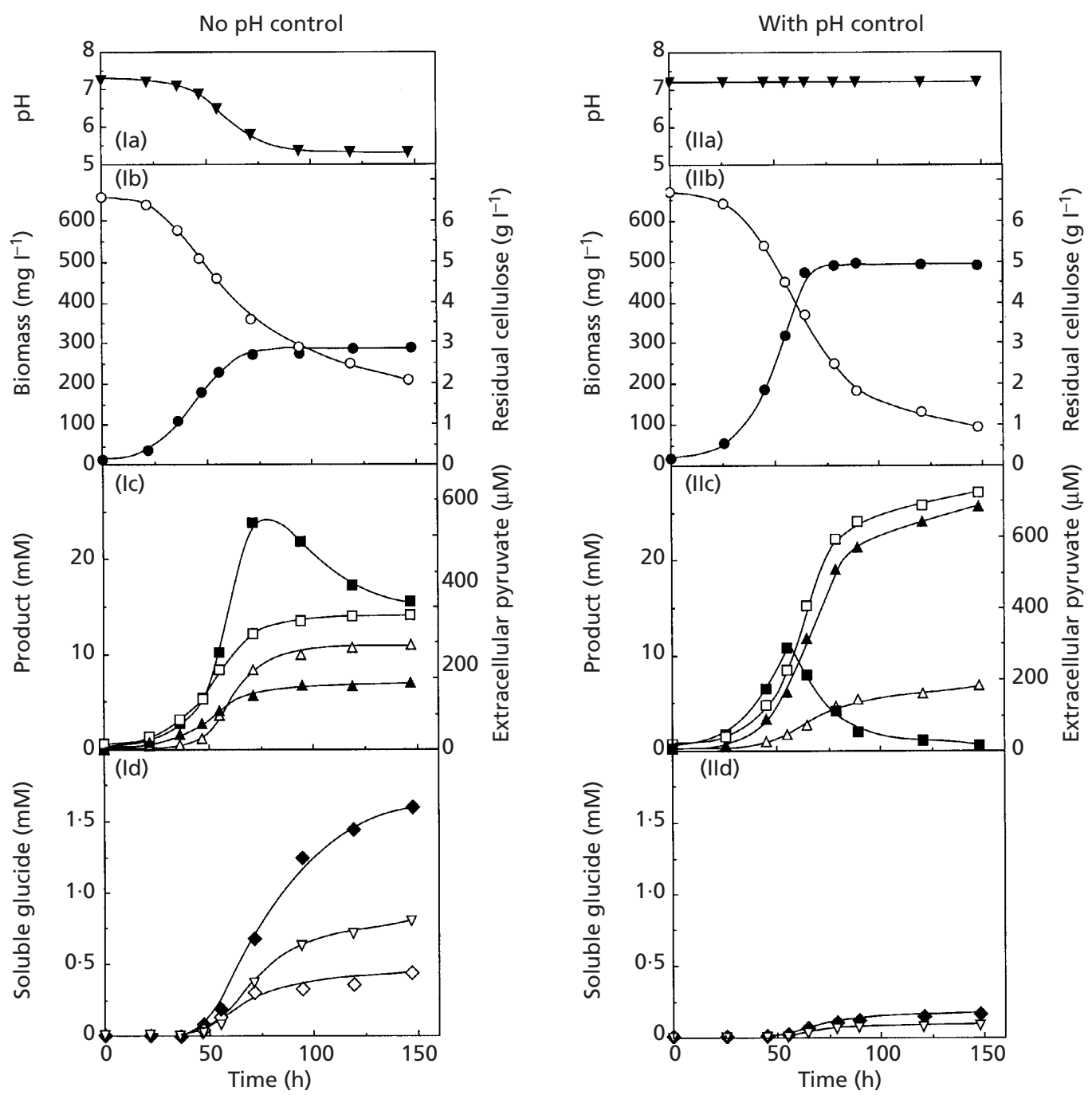

Fig. 2. $\mathrm{pH}$ variation (a), growth and residual cellulose concentration (b), metabolite concentrations (c), and soluble glucide accumulation (d) during cellulose batch fermentation without (I) and with (II) $\mathrm{pH}$ control. $\boldsymbol{\nabla}, \mathrm{pH} ; \mathrm{O}$, cellulose; $\boldsymbol{\bullet}$, biomass; $\square$, acetate; $\boldsymbol{\Delta}$, ethanol; $\triangle$, lactate; $\mathbf{\square}$, extracellular pyruvate; $\nabla$, glucose; $\diamond$, cellobiose; $\diamond$, cellotriose.

pyruvate concentrations attained in the course of fermentation were higher in a non-pH-controlled run. Moreover, with the $\mathrm{pH}$ controlled at 7.2, pyruvate was reconsumed in the course of the fermentation more rapidly than without $\mathrm{pH}$ control. Thus once growth stopped, biocatabolic activity of cells ceased in the non$\mathrm{pH}$-controlled culture whereas in the $\mathrm{pH}$-controlled condition the degraded cellulose was further metabolized by resting cells.

The kinetic profile for individual soluble glucide accumulation indicated that it was a non-growthassociated event (Figs 2Id and 2IId). A higher level of soluble cello-oligosaccharides was achieved in fermentation without $\mathrm{pH}$ control: up to $1.56 \mathrm{mM}$ cellobiose was detected as well as $0.36 \mathrm{mM}$ cellotriose. With $\mathrm{pH}$ control, the sugar level in the broth medium was very limited since only $0 \cdot 16 \mathrm{mM}$ cellobiose was found and no cellotriose could be detected. In both culture conditions, longer cellodextrins could not be detected either by HPLC or by TLC techniques. Inasmuch as cellulose was degraded to a greater extent in the $\mathrm{pH}$-controlled culture, the difference in accumulation of sugars may reflect a difference in the cellulose substrate, e.g. its surface area (Weimer et al., 1990, 1991a; Fields \& Russell, 2000), at the time cultures entered stationary phase, and/or differences in metabolism of stationaryphase cells.

\section{Effect of pH on the growth and metabolite production of $\mathrm{C}$. cellulolyticum in cellulose continuous culture}

Growth parameters, notably end products measured at each steady state, as a function of the $\mathrm{pH}$ value are compiled in Table 1. C. cellulolyticum was grown in continuous culture under cellulose-limited conditions and at a constant dilution rate of $0.053 \mathrm{~h}^{-1}$ with $\mathrm{pH}$ 
Table 1. Fermentation parameters from continuous steady-state cultures of C. cellulolyticum as a function of environmental $\mathrm{pH}$ at $D=0.053 \mathrm{~h}^{-1}$

The cellulose input was $0.37 \%(\mathrm{w} / \mathrm{v})$. Values are the means of samples at steady state and are shown \pm standard deviation where appropriate. Where no standard deviation is given, individual values did not vary from the mean by more than $10 \%$.

\begin{tabular}{|c|c|c|c|c|c|}
\hline \multirow[t]{2}{*}{ Parameter } & \multicolumn{5}{|c|}{ Results obtained at $\mathrm{pH}$ value of } \\
\hline & $7 \cdot 4$ & $7 \cdot 2$ & $7 \cdot 0$ & $6 \cdot 8$ & $6 \cdot 4$ \\
\hline Biomass $\left(\mathrm{g} \mathrm{l}^{-1}\right)$ & $0 \cdot 129 \pm 0 \cdot 011$ & $0 \cdot 207 \pm 0 \cdot 018$ & $0 \cdot 234 \pm 0 \cdot 021$ & $0 \cdot 164 \pm 0 \cdot 014$ & $0 \cdot 056 \pm 0 \cdot 005$ \\
\hline $\begin{array}{l}\text { Cellulose consumed } \\
\text { (mM hexose eq) }\end{array}$ & $4 \cdot 75 \pm 0 \cdot 22$ & $7 \cdot 46 \pm 0 \cdot 38$ & $8 \cdot 14 \pm 0 \cdot 41$ & $5 \cdot 31 \pm 0 \cdot 25$ & $1.79 \pm 0.09$ \\
\hline$q_{\text {cellulose }}\left[\mathrm{mmol}(\mathrm{g} \text { cells })^{-1} \mathrm{~h}^{-1}\right]$ & $1 \cdot 95$ & $1 \cdot 91$ & $1 \cdot 84$ & $1 \cdot 72$ & $1 \cdot 69$ \\
\hline$q_{\text {pyruvate }}\left[\mathrm{mmol}(\mathrm{g} \text { cells })^{-1} \mathrm{~h}^{-1}\right]$ & $2 \cdot 76$ & $2 \cdot 63$ & $2 \cdot 46$ & $2 \cdot 31$ & $2 \cdot 18$ \\
\hline \multicolumn{6}{|l|}{ Product yield $(\%)^{*}$} \\
\hline Acetate & $70 \cdot 3$ & $68 \cdot 11$ & $67 \cdot 2$ & $62 \cdot 3$ & $47 \cdot 7$ \\
\hline Ethanol & $29 \cdot 3$ & $30 \cdot 4$ & $30 \cdot 8$ & $33 \cdot 4$ & $44 \cdot 8$ \\
\hline Lactate & $0 \cdot 5$ & $1 \cdot 5$ & $2 \cdot 0$ & $4 \cdot 4$ & $7 \cdot 5$ \\
\hline $\begin{array}{l}q_{\text {extracellular pyruvate }} \\
{\left[\mu \mathrm{mol}(\mathrm{g} \mathrm{cells})^{-1} \mathrm{~h}^{-1}\right]}\end{array}$ & $3 \cdot 91$ & $9 \cdot 47$ & $7 \cdot 29$ & $13 \cdot 90$ & $32 \cdot 42$ \\
\hline Glycogen $\left[\mathrm{mg}\left({\left.\text { g cells })^{-1}\right]}^{-1}\right.\right.$ & $91 \cdot 5 \pm 2 \cdot 6$ & $96 \cdot 8 \pm 2 \cdot 9$ & $107 \cdot 3 \pm 4 \cdot 0$ & $78 \cdot 8 \pm 2 \cdot 3$ & $62 \cdot 7 \pm 1 \cdot 7$ \\
\hline Extracellular proteins $\left(\mathrm{mg} \mathrm{l}^{-1}\right)$ & $11 \cdot 3 \pm 0 \cdot 7$ & $18 \cdot 5 \pm 0 \cdot 9$ & $18 \cdot 2 \pm 0 \cdot 8$ & $15 \cdot 4 \pm 0 \cdot 6$ & $4 \cdot 0 \pm 0 \cdot 3$ \\
\hline Free amino acids $\left(\mathrm{mg} \mathrm{l}^{-1}\right)$ & $33 \cdot 4 \pm 1 \cdot 6$ & $63 \cdot 3 \pm 3 \cdot 6$ & $62 \cdot 9 \pm 4 \cdot 0$ & $47 \cdot 1 \pm 2 \cdot 1$ & $13 \cdot 9 \pm 0 \cdot 8$ \\
\hline Carbon recovery $(\%)$ & $94 \cdot 7$ & $94 \cdot 2$ & $92 \cdot 3$ & $95 \cdot 3$ & $91 \cdot 4$ \\
\hline
\end{tabular}

* The product yields were expressed as percentages of $q_{\text {pyruvate }}$.

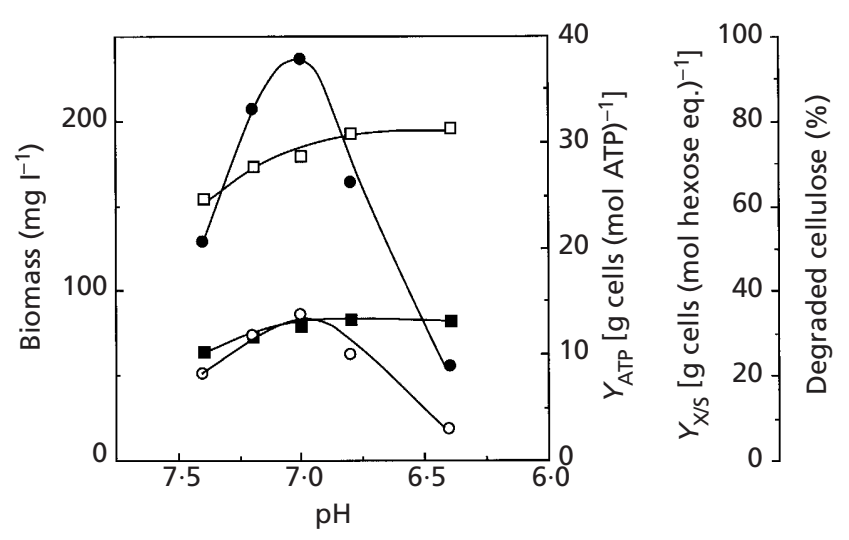

Fig. 3. Dry weight of cells, percentage cellulose degradation, and molar and energetic growth yields during growth of $C$. cellulolyticum in continuous culture $\left(D=0.053 \mathrm{~h}^{-1}\right)$ under various $\mathrm{pH}$ conditions and with cellulose as sole carbon and energy source. Biomass; $O$, percentage cellulose degradation; $\square, Y_{\mathrm{X} / \mathrm{S}} ; \mathbf{\square}, Y_{\mathrm{ATP}}$.

values ranging from $7 \cdot 4$ to $6 \cdot 4$. The primary metabolic end products of the cellulose fermentation were acetate, ethanol, lactate, $\mathrm{H}_{2}$ and $\mathrm{CO}_{2}$. In addition to carbon conversion into biomass, amino acids and extracellular proteins were also detected in the supernatant (Table 1). Exopolysaccharides were readily observable by micro-

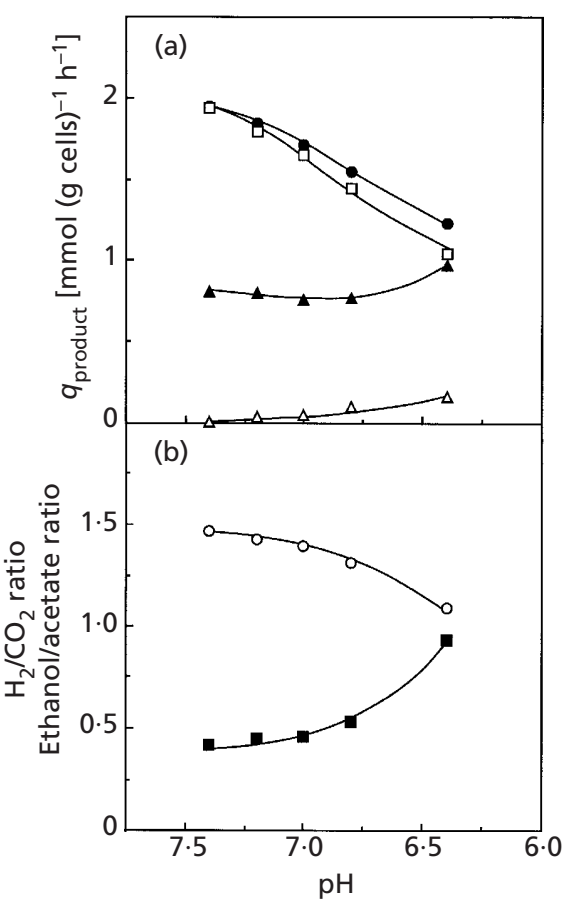

Fig. 4. Specific production rate (a) and product ratio (b) during growth of $C$. cellulolyticum in cellulose-fed continuous culture $\left(D=0.053 \mathrm{~h}^{-1}\right)$ under various $\mathrm{pH}$ conditions. $\square, q_{\text {acetate }} ; \boldsymbol{\Delta}$, $q_{\text {ethanol }} ; \triangle, q_{\text {lactate }} ; q_{\mathrm{H}^{+}} ; \bigcirc, \mathrm{H}_{2} / \mathrm{CO}_{2} ; \mathbf{\square}$, ethanol/acetate ratio. 
Table 2. Redox and energetic balance of $C$. cellulolyticum cells at steady state

\begin{tabular}{|c|c|c|c|c|c|}
\hline \multirow[t]{2}{*}{ Parameter } & \multicolumn{5}{|c|}{ Results obtained at $\mathrm{pH}$ value of } \\
\hline & $7 \cdot 4$ & $7 \cdot 2$ & $7 \cdot 0$ & $6 \cdot 8$ & $6 \cdot 4$ \\
\hline $\mathrm{NADH}\left[\mu \mathrm{mol}(\mathrm{g} \text { cells })^{-1}\right]$ & $4 \cdot 75 \pm 0 \cdot 85$ & $4 \cdot 68 \pm 0 \cdot 90$ & $4 \cdot 90 \pm 0 \cdot 97$ & $5 \cdot 26 \pm 1 \cdot 02$ & $5 \cdot 93 \pm 1 \cdot 14$ \\
\hline $\mathrm{NAD}^{+}\left[\mu \mathrm{mol}\left(\mathrm{g} \mathrm{cells}^{-1}\right]\right.$ & $11 \cdot 31 \pm 2 \cdot 22$ & $12 \cdot 01 \pm 2 \cdot 36$ & $11 \cdot 40 \pm 2.25$ & $11 \cdot 22 \pm 2 \cdot 17$ & $11 \cdot 69 \pm 2 \cdot 33$ \\
\hline $\mathrm{NADH} / \mathrm{NAD}^{+}$ratio & $0 \cdot 42$ & $0 \cdot 39$ & $0 \cdot 43$ & $0 \cdot 47$ & 0.51 \\
\hline$q_{\mathrm{NADH}}$ produced $\left[\mathrm{mmol}(\mathrm{g} \text { cells })^{-1} \mathrm{~h}^{-1}\right]$ & $2 \cdot 76$ & $2 \cdot 63$ & $2 \cdot 46$ & $2 \cdot 31$ & $2 \cdot 18$ \\
\hline$q_{\mathrm{NADH}}$ used $\left[\mathrm{mmol}(\mathrm{g} \text { cells })^{-1} \mathrm{~h}^{-1}\right]$ & $1 \cdot 63$ & $1 \cdot 64$ & $1 \cdot 56$ & $1 \cdot 64$ & $2 \cdot 11$ \\
\hline$q_{\mathrm{NADH} \text { produced }} / q_{\mathrm{NADH} \text { used }}$ ratio & $1 \cdot 69$ & $1 \cdot 61$ & $1 \cdot 57$ & $1 \cdot 41$ & $1 \cdot 03$ \\
\hline Pool ATP + ADP $\left[\mu \mathrm{mol}(\mathrm{g} \text { cells })^{-1}\right]$ & $5 \cdot 13$ & $4 \cdot 79$ & $5 \cdot 39$ & $5 \cdot 92$ & $6 \cdot 11$ \\
\hline $\mathrm{ATP} / \mathrm{ADP}$ ratio & $0 \cdot 50$ & $0 \cdot 46$ & $0 \cdot 43$ & $0 \cdot 39$ & $0 \cdot 34$ \\
\hline$q_{\mathrm{ATP}}\left[\mathrm{mmol}(\mathrm{g} \text { cells })^{-1} \mathrm{~h}^{-1}\right]$ & $4 \cdot 53$ & $4 \cdot 26$ & 3.97 & $3 \cdot 61$ & $3 \cdot 08$ \\
\hline ATP-Eff* & $2 \cdot 32$ & $2 \cdot 23$ & $2 \cdot 15$ & $2 \cdot 10$ & $1 \cdot 82$ \\
\hline
\end{tabular}

*ATP-Eff is the ATP generation efficiency.

Table 3. Estimation of carbon flow based on the steady-state values from a cellulose chemostat of $C$. cellulolyticum at $D=0.053 \mathrm{~h}^{-1}$ as a function of environmental $\mathrm{pH}$

Carbon flow was calculated as specified in Methods. See Fig. 1 for the metabolic pathways. The values are expressed both as meq C $(\mathrm{g} \text { cells })^{-1} \mathrm{~h}^{-1}$ and, in parentheses, as a percentage of the specific rate of cellulose consumed $\left(q_{\text {cellulose }}\right)$.

\begin{tabular}{|c|c|c|c|c|c|}
\hline \multirow[t]{2}{*}{ Carbon flow } & \multicolumn{5}{|c|}{ Results obtained at $\mathrm{pH}$ value of } \\
\hline & $7 \cdot 4$ & $7 \cdot 2$ & $7 \cdot 0$ & $6 \cdot 8$ & $6 \cdot 4$ \\
\hline$q_{\text {cellulose }}$ & $11 \cdot 74(100 \cdot 0)$ & $11 \cdot 46(100 \cdot 0)$ & $11 \cdot 04(100 \cdot 0)$ & $10 \cdot 56(100 \cdot 0)$ & $10 \cdot 13(100 \cdot 0)$ \\
\hline$q_{\mathrm{G} 1 \mathrm{P}}$ & $7 \cdot 39(63 \cdot 0)$ & $7 \cdot 22(63 \cdot 0)$ & $6.95(63 \cdot 0)$ & $6 \cdot 65(63 \cdot 0)$ & $6 \cdot 38(63 \cdot 0)$ \\
\hline$q_{\text {glycogen }}$ & $0 \cdot 18(1 \cdot 5)$ & $0 \cdot 19(1 \cdot 7)$ & $0 \cdot 21(1 \cdot 9)$ & $0 \cdot 16(1 \cdot 5)$ & $0 \cdot 12(1 \cdot 2)$ \\
\hline$q_{\text {exopolysaccharide }}$ & $0 \cdot 41(3 \cdot 5)$ & $0 \cdot 42(3 \cdot 7)$ & $0 \cdot 60(5 \cdot 5)$ & $0 \cdot 51(4 \cdot 8)$ & $0 \cdot 63(6 \cdot 2)$ \\
\hline$q_{\text {glucose }}$ & $4 \cdot 35(37 \cdot 0)$ & $4 \cdot 24(37 \cdot 0)$ & $4.09(37 \cdot 0)$ & $3.91(37 \cdot 0)$ & $3.75(37 \cdot 0)$ \\
\hline$q_{\text {phosphoglucomutase }}$ & $6 \cdot 80(57 \cdot 9)$ & $6.60(57.6)$ & $6 \cdot 14(55 \cdot 6)$ & $5.99(56.7)$ & $5.63(55.5)$ \\
\hline$q_{\mathrm{G} 6 \mathrm{P}}$ & $11 \cdot 15(94 \cdot 9)$ & $10 \cdot 85(94 \cdot 7)$ & $10 \cdot 23(92 \cdot 6)$ & $9 \cdot 90(93 \cdot 7)$ & $9 \cdot 38(92 \cdot 6)$ \\
\hline$q_{\text {extracellular pyruvate }}$ & $0 \cdot 01(0 \cdot 1)$ & $0 \cdot 03(0 \cdot 2)$ & $0 \cdot 02(0 \cdot 2)$ & $0 \cdot 04(0 \cdot 4)$ & $0 \cdot 10(1 \cdot 0)$ \\
\hline$q_{\text {biosynthesis }}$ & $2 \cdot 84(24 \cdot 2)$ & $2 \cdot 94(25 \cdot 7)$ & $2 \cdot 84(25 \cdot 7)$ & $2 \cdot 92(27 \cdot 6)$ & $2.78(27 \cdot 4)$ \\
\hline$q_{\text {pyruvate }}$ & $8 \cdot 31(70 \cdot 7)$ & $7 \cdot 90(69 \cdot 0)$ & $7 \cdot 39(66 \cdot 9)$ & $6 \cdot 98(66 \cdot 1)$ & $6 \cdot 60(65 \cdot 2)$ \\
\hline$q_{\text {acetyl-CoA }}$ & $5 \cdot 50(46 \cdot 9)$ & $5 \cdot 17(45 \cdot 1)$ & $4 \cdot 81(43 \cdot 6)$ & $4 \cdot 43(41 \cdot 9)$ & $4 \cdot 01(39 \cdot 6)$ \\
\hline$q_{\text {lactate }}$ & $0 \cdot 04(0 \cdot 3)$ & $0 \cdot 12(1 \cdot 0)$ & $0 \cdot 15(1 \cdot 4)$ & $0 \cdot 30(2 \cdot 9)$ & $0 \cdot 49(4 \cdot 8)$ \\
\hline$q_{\mathrm{CO}_{2}}$ & $2 \cdot 75(23 \cdot 4)$ & $2 \cdot 59(22 \cdot 6)$ & $2 \cdot 41(21 \cdot 8)$ & $2 \cdot 21(21 \cdot 0)$ & $2 \cdot 01(19 \cdot 8)$ \\
\hline$q_{\text {ethanol }}$ & $1 \cdot 62(13 \cdot 8)$ & $1 \cdot 60(13 \cdot 9)$ & $1 \cdot 51(13 \cdot 7)$ & $1 \cdot 54(14 \cdot 6)$ & $1.94(19 \cdot 2)$ \\
\hline$q_{\text {acetate }}$ & $3 \cdot 88(33 \cdot 1)$ & $3 \cdot 58(31 \cdot 2)$ & $3 \cdot 30(29 \cdot 9)$ & $2 \cdot 88(27 \cdot 3)$ & $2 \cdot 07(20 \cdot 4)$ \\
\hline
\end{tabular}

scopic examination but could not be measured as previously described (Payot et al., 1998) due to the significant interference with cellulose fibres leading to erroneous estimation of their concentration. Taking into account amino acids, proteins, fermentative end products and biomass concentration, the carbon balance ranged between 91.4 and $95.3 \%$ (Table 1 ).

As the $\mathrm{pH}$ was lowered from $7 \cdot 4$ to $7 \cdot 0$, the dry weight of cells increased (Fig. 3); with a further $\mathrm{pH}$ decline, however, the cell density decreased and a steady state of the culture could not be established at $\mathrm{pH} 6.2$ since washout occurred. Whatever the $\mathrm{pH}$ conditions, $C$. cellulolyticum always left some cellulose undigested
(Fig. 3). When the $\mathrm{pH}$ value was decreased from $7 \cdot 4$ to $7 \cdot 0$, the percentage of cellulose degradation increased from $20 \cdot 6$ to $34 \cdot 2 \%$ and then dropped to reach $7 \cdot 3 \%$ at $\mathrm{pH} 6 \cdot 4$. Whereas C. cellulolyticum showed depressed dry weight of cells at $\mathrm{pH}$ values higher than $7 \cdot 0$, the observed cell yields $\left(Y_{\mathrm{X} / \mathrm{S}}\right)$ did not decline, even at a $\mathrm{pH}$ value close to washout (Fig. 3); $\mathrm{Y}_{\mathrm{X} / \mathrm{S}}$ increased from $27 \cdot 1$ to $31.3 \mathrm{~g}$ cells (mol ATP) ${ }^{-1}$ between $\mathrm{pH} 7 \cdot 4$ and 6.4 . The energetic yield of biomass $\left(Y_{\mathrm{ATP}}\right)$ changed in the same way as $Y_{\mathrm{X} / \mathrm{S}}$; such a result means that approximately the same amount of ATP was used for the process implicated in cell growth regardless of the $\mathrm{pH}$ value.

In all runs, acetate was the main fermentative end 


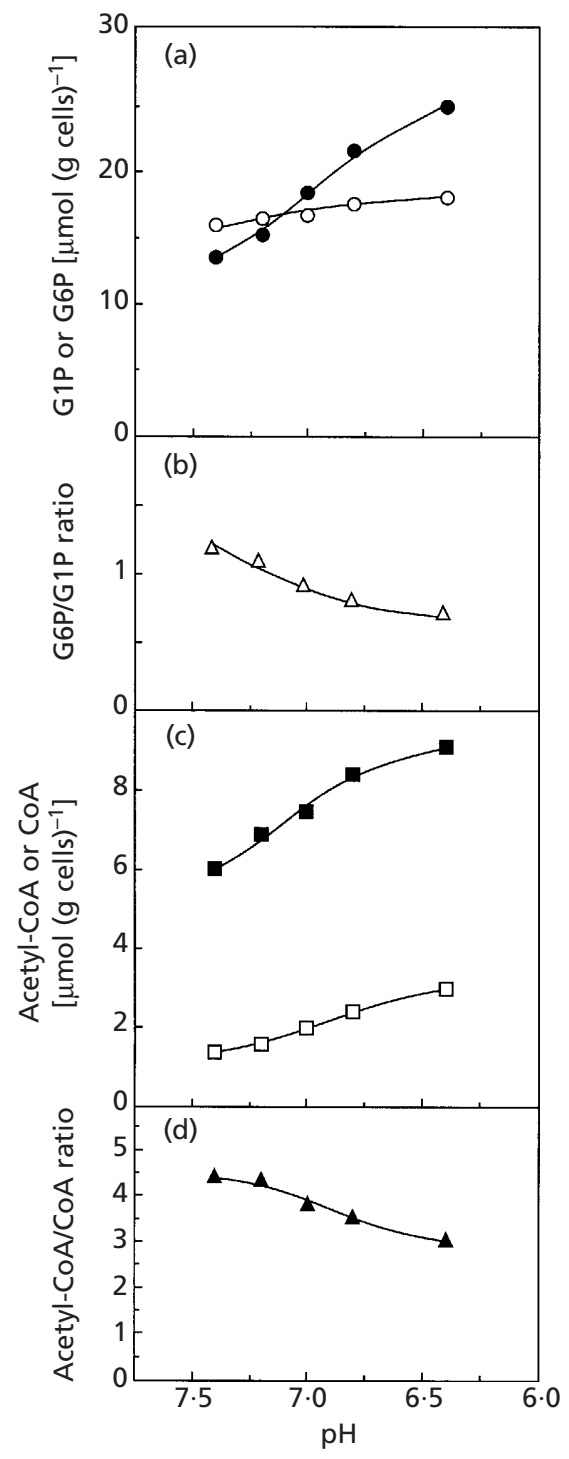

Fig. 5. Effect of $\mathrm{pH}$ on the pools $(\mathrm{a}, \mathrm{c})$ and ratio $(b, d)$ of $\mathrm{G} 1 \mathrm{P}$ and G6P $(a, b)$, and of acetyl-CoA and CoA $(c, d)$, when $C$. cellulolyticum is grown on cellulose in continuous culture at $D=0.053 \mathrm{~h}^{-1} .0, \mathrm{G} 6 \mathrm{P} ; \bullet, \mathrm{G} 1 \mathrm{P} ; \triangle, \mathrm{G} 6 \mathrm{P} / \mathrm{G} 1 \mathrm{P} ; \mathbf{\square}$, acetyl-CoA; $\square$, CoA; $\boldsymbol{\Delta}$, acetyl-CoA/CoA.

product: it represented between $70 \cdot 3$ and $47 \cdot 7 \%$ of the carbon directed towards catabolites (Table 1). With lowering of $\mathrm{pH}$, the specific production rate of ethanol increased while that of acetate declined, the latter always remaining the higher (Fig. 4a). The ethanol-to-acetate ratio increased with decreasing $\mathrm{pH}$ and reached 0.94 at pH 6.4 (Fig. 4b). In contrast, the $\mathrm{H}_{2} / \mathrm{CO}_{2}$ ratio followed a downward trend with decreasing $\mathrm{pH}$ (Fig. $4 \mathrm{~b}$ ). Lactate was also produced at all $\mathrm{pH}$ values, but whereas the specific production rate $\left(q_{\text {lactate }}\right)$ was low at $\mathrm{pH} 7 \cdot 4$, i.e. $0.01 \mathrm{mmol}\left(\mathrm{g} \mathrm{cells}^{-1} \mathrm{~h}^{-1}\right.$, it increased as the $\mathrm{pH}$ decreased, reaching $0.16 \mathrm{mmol}(\mathrm{g} \text { cells })^{-1} \mathrm{~h}^{-1}$ at $\mathrm{pH} 6.4$ (Fig. 4a). As the $\mathrm{pH}$ was lowered, the specific rate of acid production $\left(q_{\mathrm{H}^{+}}\right)$, calculated from the spectrum of acid end products formed in cellulose chemostat culture grown at the different $\mathrm{pH}$ values, continuously decreased from 1.95 to $1.23 \mathrm{mmol}$ (g cells) ${ }^{-1} \mathrm{~h}^{-1}$ (Fig. 4a).

\section{Redox and energetic balance in a cellulose-fed chemostat at various $\mathrm{pH}$ values}

The NADH balance calculated from the known metabolic pathways producing and consuming reducing equivalents, i.e. $q_{\mathrm{NADH}}$ produced $/ q_{\mathrm{NADH}}$ used , continuously decreased with $\mathrm{pH}$ from its value of 1.69 at $\mathrm{pH} 7.4$ and was approximately 1 at $\mathrm{pH} \mathrm{6.4} \mathrm{(Table} \mathrm{2).} \mathrm{Whereas}$ $\mathrm{NAD}^{+}$molecules are reduced by glyceraldehyde 3phosphate dehydrogenase during ethanol, lactate or acetate formation, only the ethanol and lactate production pathways allow the regeneration of the NAD ${ }^{+}$ pool via dehydrogenase activities. Despite the apparent imbalance at $\mathrm{pH}$ values higher than 6.4 , the intracellular $\mathrm{NADH} / \mathrm{NAD}^{+}$ratio was always lower than 1 (Table 2). At $\mathrm{pH}$ values higher than $6.4, q_{\text {lactate }}$ and $q_{\text {ethanol }}$ were then not sufficient to regenerate NADH to NAD ${ }^{+}$. This result correlated with the $\mathrm{H}_{2} / \mathrm{CO}_{2}$ ratios, which were always higher than 1 (Fig. 4b), suggesting that low lactate and ethanol production was balanced by $\mathrm{H}_{2}$ gas formation via NADH-Fd reductase and hydrogenase activities.

The stoichiometry of ATP generated over hexose eq fermented (ATP-Eff) decreased from 2.32 to 1.82 as the $\mathrm{pH}$ was lowered from $7 \cdot 4$ to $6 \cdot 4 ; q_{\mathrm{ATP}}$ also declined, from 4.53 to $3.08 \mathrm{mmol}$ (g cells) ${ }^{-1} \mathrm{~h}^{-1}$ (Table 2). The ATP + ADP pool fluctuated between 4.79 and $6 \cdot 11 \mu \mathrm{mol}$ (g cells $)^{-1}$, while the ATP/ADP ratio decreased from 0.50 to 0.34 with environmental acidification (Table 2 ). This variation was probably correlated with the change of the end products, namely the decrease of acetate biosynthesis.

\section{Metabolic flux analysis of cells grown on cellulose in an acid environment}

The metabolism of C. cellulolyticum when grown on cellulose is depicted in Fig. 1. With acidification of the growth medium from $\mathrm{pH} 7 \cdot 4$ to $6 \cdot 4$, the rate of cellulose consumption declined from 11.74 to $10 \cdot 13 \mathrm{meq} \mathrm{C}$ (g cells) $)^{-1} \mathrm{~h}^{-1}$ (Table 3 ). The proportion of the cellulose converted into biomass, free amino acids and extracellular proteins, i.e. $q_{\text {biosynthesis }}$, varied from 24.2 to $27.4 \%$ with this $\mathrm{pH}$ decline (Table 3 ); considering each, the biomasss formation increased from $17 \cdot 9$ to $20.7 \%$ of the original carbon while cellulose conversion into amino acid and extracellular protein accounted for around 5.3 and $1.6 \%$ of the carbon uptake respectively. Another part of the carbon flow was directed towards metabolite fermentation, i.e. acetate, ethanol, $\mathrm{CO}_{2}$, extracellular pyruvate and lactate, which as a whole decreased from $70 \cdot 7$ to $65.2 \%$ of the cellulose consumed (Table 3). Metabolism distributed carbon differently over known catabolic routes as the $\mathrm{pH}$ declined. Carbon flow through the $\mathrm{CO}_{2}$ and acetate formation pathways declined from $23 \cdot 4$ to $19 \cdot 8 \%$ and from $33 \cdot 1$ to $20 \cdot 4 \%$ respectively. However, ethanol formation increased from 13.8 to $19 \cdot 2 \%$ of the carbon consumed; lactate 
Table 4. Specific enzymic activity and flux relative to available enzyme activity in C. cellulolyticum cell extract at steady state

\begin{tabular}{|c|c|c|c|c|c|c|c|c|c|c|}
\hline \multirow[t]{3}{*}{ Enzyme* } & \multicolumn{10}{|c|}{ Results obtained at $\mathrm{pH}$ value of } \\
\hline & \multicolumn{2}{|l|}{$7 \cdot 4$} & \multicolumn{2}{|c|}{$7 \cdot 2$} & \multicolumn{2}{|l|}{$7 \cdot 0$} & \multicolumn{2}{|c|}{$6 \cdot 8$} & \multicolumn{2}{|l|}{$6 \cdot 4$} \\
\hline & SEA $\dagger$ & $R \ddagger$ & SEA & $R$ & SEA & $R$ & SEA & $R$ & SEA & $R$ \\
\hline PTA & $0 \cdot 83 \pm 0.08$ & $19 \cdot 1$ & $0.97 \pm 0.07$ & $24 \cdot 0$ & $0.71 \pm 0.08$ & $19 \cdot 2$ & $0 \cdot 61 \pm 0.05$ & $18 \cdot 8$ & $0.46 \pm 0.06$ & $19 \cdot 5$ \\
\hline $\mathrm{AK}$ & $0.88 \pm 0.09$ & $20 \cdot 6$ & $0 \cdot 83 \pm 0 \cdot 10$ & $20 \cdot 1$ & $0.64 \pm 0.06$ & $17 \cdot 2$ & $0.49 \pm 0.05$ & $15 \cdot 2$ & $0.30 \pm 0.03$ & $12 \cdot 9$ \\
\hline $\mathrm{AADH}$ & $0 \cdot 12 \pm 0 \cdot 01$ & $6 \cdot 3$ & $0 \cdot 18 \pm 0.02$ & $10 \cdot 1$ & $0 \cdot 21 \pm 0 \cdot 01$ & $12 \cdot 4$ & $0 \cdot 19 \pm 0 \cdot 01$ & $11 \cdot 3$ & $0 \cdot 22 \pm 0.03$ & $9 \cdot 8$ \\
\hline $\mathrm{ADH}$ & $0.29 \pm 0.02$ & $15 \cdot 7$ & $0.28 \pm 0.03$ & $15 \cdot 6$ & $0.25 \pm 0.02$ & $14 \cdot 9$ & $0 \cdot 23 \pm 0 \cdot 01$ & $13 \cdot 3$ & $0.27 \pm 0.03$ & $12 \cdot 3$ \\
\hline LDH & $0.15 \pm 0.01$ & $529 \cdot 5$ & $0.19 \pm 0.03$ & $215 \cdot 3$ & $0 \cdot 18 \pm 0.01$ & $155 \cdot 4$ & $0 \cdot 14 \pm 0.01$ & $62 \cdot 9$ & $0.17 \pm 0.02$ & $46 \cdot 1$ \\
\hline $\mathrm{PFO}$ & $0.61 \pm 0.05$ & $9 \cdot 8$ & $0.66 \pm 0.03$ & $11 \cdot 2$ & $0.34 \pm 0.04$ & $6 \cdot 3$ & $0 \cdot 13 \pm 0.02$ & $2 \cdot 5$ & $0.08 \pm 0.01$ & $1 \cdot 8$ \\
\hline
\end{tabular}

*PTA, phosphotransacetylase; AK, acetate kinase; AADH, acetaldehyde dehydrogenase; ADH, alcohol dehydrogenase; LDH, L-lactate dehydrogenase; PFO, pyruvate-Fd oxidoreductase.

† SEA is the specific activity of enzyme expressed in $\mu \mathrm{mol} \min ^{-1}$ (mg protein $)^{-1}$.

$\ddagger R$ is the ratio of specific enzymic activity to metabolic flux through the considered metabolic pathway. Flux was previously expressed as $\mu \mathrm{mol}(\mathrm{mg} \text { protein })^{-1} \mathrm{~min}^{-1}$.

formation also increased, from only $0.3 \%$ at $\mathrm{pH} 7 \cdot 4$ to $4 \cdot 8 \%$ at $\mathrm{pH} 6 \cdot 4$. At the same time, the proportion of carbon flowing towards extracellular pyruvate rose from $0 \cdot 1$ to $1 \%$ with lower environmental $\mathrm{pH}$.

As the $\mathrm{pH}$ decreased, the G6P pool slightly increased (Fig. 5a); in terms of turn-over, this pool varied from $116 \cdot 4$ to $86 \cdot 5 \mathrm{~h}^{-1}$ from $\mathrm{pH} 7 \cdot 4$ to $6 \cdot 4$. This result was correlated with the concomitant decrease of the carbon flow through glycolysis on the one hand and the increase of the carbon flow through the biosynthesis pathway on the other, as the environmental $\mathrm{pH}$ fell. The $q_{\mathrm{G} 6 \mathrm{P}}$ decreased from 11.15 to 9.38 meq C (g cells) ${ }^{-1} \mathrm{~h}^{-1}$ with acidification, which represented $94.9-92.6 \%$ of the original carbon metabolized (Table 3). As for the G1P pool, it increased with decreasing pH (Fig. 5a) which was expressed as a decrease of the turn-over of this pool from 91.3 to $42.7 \mathrm{~h}^{-1}$ from $\mathrm{pH} 7 \cdot 4$ to 6.4 . As a result the G6P/G1P ratio ranged from 1.19 to 0.73 with decreasing environmental $\mathrm{pH}$ (Fig. 5b). G1P is an important node in cellulose metabolism since carbon could either flow down glycolysis via phophoglucomutase or stored as glycogen, or be converted into exopolysaccharide. $q_{\text {phosphoglucomutase }}$ decreased from 6.80 to $5.63 \mathrm{meq} \mathrm{C}$ (g cells) $)^{-1} \mathrm{~h}^{-1}$ with lowering of $\mathrm{pH}$; when expressed as a percentage of $q_{\text {cellulose }}$, this flux ranged from 57.9 to $55.5 \%$ (Table 3 ). The proportion of carbon through $q_{\text {glycogen }}$ varied from 1.2 to $1.9 \%$, while $q_{\text {exopolysaccharide }}$ represented $3.5 \%$ of the carbon uptake at $\mathrm{pH} 7.4$ to reach $6.2 \%$ at $\mathrm{pH} 6.4$ (Table 3 ).

The CoA pool was fuelled by phosphotransacetylase and acetaldehyde dehydrogenase, whereas acetyl-CoA was formed via pyruvate-Fd oxidoreductase activity (Fig. 1). With lowering of the $\mathrm{pH}$, both pools increased (Fig. 5c), however the acetyl-CoA/CoA ratio decreased from 4.46 to 3.06 (Fig. 5d). Such results were correlated with (i) the rerouteing of carbon flow towards biosynthesis, which increased from $24 \cdot 2$ to $27 \cdot 4 \%$ at the expense of $q_{\text {pyruvate}}$, which decreased from 70.7 to $65 \cdot 2$ meq C (g cells) ${ }^{-1} \mathrm{~h}^{-1}$ (Table 3 ) and (ii) the decrease of carbon flowing through acetate production from $33 \cdot 1$ to $20.4 \%$ whereas it increased only from $13 \cdot 8$ to $19 \cdot 2 \%$ through the ethanol pathway as $\mathrm{pH}$ declined (Table 3).

\section{Enzymic activities as a function of environmental pH}

The influence of environmental $\mathrm{pH}$ on the specific activities of the enzymes studied is compiled in Table 4. In vitro, $\mathrm{PFO}, \mathrm{PTA}, \mathrm{AK}$ and $\mathrm{AADH}$ activities were higher under conditions giving higher in vivo specific production rates (Table 4 ). When the carbon flow was expressed as $\mu \mathrm{mol}(\mathrm{mg} \text { protein })^{-1} \mathrm{~h}^{-1}$ from previously calculated values (Table 3 ), $R$ (the ratio of the specific enzyme activity to metabolic rate) could be calculated (Holms, 1996). In the metabolic branch leading to acetate production through PTA and AK, $R$ fluctuated between 18.8 and $24 \cdot 0$, and between 20.6 and $12 \cdot 9$, respectively, as $\mathrm{pH}$ decreased (Table 4). $R$ for the enzymes of the ethanol pathway varied between 6.3 and $12 \cdot 4$, and between 15.7 and $12 \cdot 3$ for $\mathrm{AADH}$ and $\mathrm{ADH}$, respectively (Table 4). At each step in the central metabolic pathways, the intracellular concentration of substrates, products, cofactors or effector molecules as well as intracellular ionic strength, redox potential or $\mathrm{pH}$ can influence the partition and regulation of the carbon flux (Holms, 1986). Nevertheless, the fact that fluxes were much less than the available enzyme activity indicated that the carbon flows were determined by the concentration of substrate available rather than the enzyme activity (Holms, 1996). Despite the variation of enzyme biosynthesis, the amount of these enzymes was always sufficient to catabolize the flowing carbon since $R$ was much higher than 1 . At $\mathrm{pH} 7 \cdot 4$, for the lactate formation pathway, $R$ was very high, i.e. 529.5. This indicated that although LDH was readily available, little carbon was catabolized by this metabolic pathway. As 
the $\mathrm{pH}$ decreased, however, $R$ declined to $46 \cdot 1$, indicating that the LDH was more and more implicated in carbon conversion (Table 4). As for the metabolic route through PFO, $R$ was in the same range as PTA, AK, $\mathrm{AADH}$ or $\mathrm{ADH}$ for environmental $\mathrm{pH}$ values between $7 \cdot 4$ and $7 \cdot 0$, i.e. $R$ between 6.3 and 11.2 (Table 4), indicating that the fluxes were much less than the available enzyme activity. Yet for a $\mathrm{pH}$ lower than $7 \cdot 0$, $R$ markedly decreased and reached 1.8 at $\mathrm{pH} 6.4$ (Table 4). Then both biosynthesis and catalytic efficiency of $\mathrm{PFO}$ declined with $\mathrm{pH}$ since the specific enzyme activity and $q_{\text {acetyl-CoA }}$ decreased (Tables 3 and 4).

\section{DISCUSSION}

Contrary to what was first observed by Giallo et al. (1983), $\mathrm{pH}$ control during batch culture fermentation of C. cellulolyticum greatly influenced cell growth and metabolism. In fact, maintaining the $\mathrm{pH}$ at $7 \cdot 2$, increased cell density, enhanced ethanol and acetate production and raised the extent of cellulose hydrolysis, but did not increase the amount of soluble glucides formed, contrary to what was observed in non-pH-controlled fermentation. As previously observed with increasing the concentration of cellulose (Desvaux et al., 2000), the maximum rate of cellulose degradation observed in $\mathrm{pH}$-controlled cultivation reflects the higher cell mass compared to a non-pH-controlled culture. Cellulolysis continued after the cessation of growth and a high level of soluble glucide accumulation was only observed in a non-pH-controlled culture. The gain in cellulose degradation achieved under $\mathrm{pH}$ control was offset by catabolite production rather than soluble sugar accumulation.

In continuous culture, maximum cell density was obtained at $\mathrm{pH} 7 \cdot 0$, but as the $\mathrm{pH}$ declined from $7 \cdot 0$ to 6.4 at constant $D$, biomass was lowered more than fourfold. At the same time, the specific rate of cellulose consumption, however, decreased only from 1.84 to 1.69 meq C $(\mathrm{g} \text { cells })^{-1} \mathrm{~h}^{-1}$. Thus environmental acidification influenced chiefly the biomass formation rather than cellulose degradation and assimilation. C. cellulolyticum did not show depressed yields and the transition to wash-out appeared abrupt. This result would be more consistent with a direct effect on a cellular constituent, such as the negative effect of acid on an enzyme or transport protein (Russell \& Dombrowski, 1980; Russell \& Diez-Gonzalez, 1998).

During cellulose catabolism by C. cellulolyticum, soluble $\beta$-glucans are first converted into G1P and G6P (Desvaux et al., 2000). With environmental acidification, the G1P pool increased, since the proportion of carbon flowing via phosphoglucomutase varied between $57 \cdot 9$ and $55.5 \%$. The remaining G1P was directed towards exopolysaccharides (up to $9.9 \%$ of the G1P) rather than glycogen synthesis $(3.0 \%$ maximum of the G1P), both allowing dissipation of carbon surplus (Guedon et al., $2000 \mathrm{~b}$ ). As the culture $\mathrm{pH}$ was lowered, the flow through glycolysis decreased while carbon directed to biosynthesis increased; as a result, the G6P pool was between 15.9 and $18.1 \mu \mathrm{mol}(\mathrm{g} \text { cells })^{-1}$. Compared with conditions of uncoupling between catabolism and anabolism encountered during ammonium-limited chemostat performed with cellobiose (Guedon et al., 2000a), the excess of carbon at the G1P-G6P branch point was here limited; in fact, exopolysaccharides and glycogen could represent up to 16.0 and $21.4 \%$ respectively of the cellobiose consumed and cellotriose was detected extracellularly (Guedon et al., 2000a).

The increase of the acetyl-CoA pool was corroborated by the analysis of carbon flux; the proportion of cellulose consumed flowing through PFO diminished as the $\mathrm{pH}$ declined, as did the ratio of specific enzymic activity to metabolic flux $(R)$, and the flux was rerouted away from acetate production. The acetyl-CoA/CoA ratio decrease was paralleled by decreases in $\mathrm{H}_{2} / \mathrm{CO}_{2}$ and $q_{\mathrm{NADH}}$ produced $/ q_{\mathrm{NADH}}$ used . Despite the variation of the NADH balance, calculated from catabolic pathways producing and consuming reducing equivalents, the intracellular $\mathrm{NADH} / \mathrm{NAD}^{+}$ratio was well regulated. Such a result is in good agreement with the model of Decker et al. (1976), where the NADH-Fd reductase is activated by the acetyl-CoA and inhibited by CoA and which underlines that the fates of NADH and acetylCoA regulation are interwined. From acetyl-CoA, acetate was mainly formed but the flux split differently as the environment was acidified, favouring ethanol production. In addition, as $\mathrm{pH}$ declined, the level of lactate production rose and coincided with the pyruvate leak, indicating that PFO could no longer support carbon flowing from glycolysis, $R$ decreasing to 1.8 at $\mathrm{pH} 6.4$. Whatever the $\mathrm{pH}$, LDH was always biosynthesized. This enzyme operated mainly as the $\mathrm{pH}$ declined but always remained in excess since even at $\mathrm{pH} 6 \cdot 4, \mathrm{R}$ was 46.1. In these experimental conditions, LDH allowed draining off part of the pyruvate surplus. At high $\mathrm{pH}$ values, $\mathrm{H}_{2} / \mathrm{CO}_{2}$ ratios higher than 1 suggested that $\mathrm{H}_{2}$ was produced via NADH-Fd reductase and hydrogenase activites in addition to pyruvate-Fd oxidoreductase and hydrogenase activities. With lower $\mathrm{pH}$ values, this ratio decreased and was compensated by the increase of ethanol production until washout occurred.

Reinvestigation of cellulose degradation by C. cellulolyticum (Desvaux et al., 2000) showed marked differences in the catabolism of this bacterium as compared with the first investigations carried out (Giallo et al., 1985). The present paper demonstrates that the inhibition of growth first observed with batch culture performed in penicillin flasks sealed with butyl rubber stoppers and without shaking of the medium (Giallo et al., 1983, 1985) is mainly the result of low $\mathrm{pH}$ due to acid production in the course of fermentation. The range of $\mathrm{pH}$ allowing maximum cell density is restricted; strict control of $\mathrm{pH}$ is therefore necessary to obtain the optimum cellulolytic performance in biotechnological processes using C. cellulolyticum. Cellulolytic bacteria so far investigated cannot grow at $\mathrm{pH}$ values significantly less than 6.0 (Stewart, 1977; Russell \& Dombrowski, 1980; Russell \& Diez-Gonzalez, 1998). However, it is well established that in anaerobic habitats, particularly in the natural environment, high 
fermentation acid concentrations and, as a result, low $\mathrm{pH}$ values are often encountered (Ljungdahl \& Eriksson, 1985; Goodwin \& Zeikus, 1987). Since these bacteria have not developed resistance to low $\mathrm{pH}$ environments, this implies that they have evolved in an ecological niche where competition for efficient metabolism in acidic conditions is not crucially important. In the same way that growth of C. cellulolyticum under an excess of nutrients (Guedon et al., 1999b) or with an easily available carbon source, such as soluble glucides, appeared as aberrations considering the natural bacterial ecosystem (Desvaux et al., 2000, 2001), cultures without $\mathrm{pH}$ control have been shown to be detrimental for optimum growth of this bacterium. These data from monospecies laboratory culture must be extrapolated to microbial ecosystems to explain the maintenance of $C$. cellulolyticum in natural environments. Clearly much remains to be learned about the complex interactions in which this bacterium takes part in microbiota (Kuznetsov et al., 1979; Ljungdahl \& Eriksson, 1985; Leschine, 1995; Costerton et al., 1995).

\section{ACKNOWLEDGEMENTS}

This work was supported by the Commission of European Communities FAIR programme (contract no. CT95-0191 [DG 12 SSMA]) and by the programme Agrice (Contract no. 9701041).

The authors thank G. Raval for technical assistance and E. McRae for correcting the English and for critical reading of the manuscript.

\section{REFERENCES}

Bayer, E. A. \& Lamed, R. (1992). The cellulose paradox: pollutant par excellence and/or a reclaimable natural resource? Biodegradation 3, 171-188.

Bayer, E. A., Shoham, Y., Tormo, J. \& Lamed, R. (1996). The cellulosome: a cell surface organelle for the adhesion to and degradation of cellulose. In Bacterial Adhesion: Molecular and Ecological Diversity, pp. 155-182. Edited by M. Fletcher. New York: Wiley-Liss.

Bayer, E. A., Chanzy, H., Lamed, R. \& Shoham, Y. (1998). Cellulose, cellulases and cellulosomes. Curr Opin Struct Biol 8, 548-557.

Béguin, P. \& Lemaire, M. (1996). The cellulosome: an exocellular, multiprotein complex specialized in cellulose degradation. Crit Rev Biochem Mol Biol 31, 201-236.

Boisset, C., Chanzy, H., Henrissat, B., Lamed, R., Shoham, Y. \& Bayer, E. A. (1999). Digestion of crystalline cellulose substrates by Clostridium thermocellum cellulosome: structural and morphological aspects. Biochem J 340, 829-835.

Collins, M. D., Lawson, P. A., Willems, A., Cordoba, J. J., Fernandez-Garayzabal, J., Garcia, P., Cai, J., Hippe, H. \& Farrow, J. A. E. (1994). The phylogeny of the genus Clostridium: proposal of five new genera and eleven species combinations. Int J Syst Bacteriol 44, 812-826.

Costerton, J. W., Lewandowski, Z., Caldwell, D. E., Korber, D. R. \& Lappin-Scott, H. M. (1995). Microbial biofilms. Annu Rev Microbiol 49, 711-745.

Decker, K., Rössle, M. \& Kreusch, J. (1976). The role of nucleotides in the regulation of the energy metabolism of Clostridium kluyveri. In Microbial Production and Utilization of Gases, pp. 75-83. Edited by H. G. Schlegel, G. Gottschalk \& N. Pfennig. Göttingen: Akademie der Wissenshaften zu Göttingen.

Desai, R. P., Harris, L. M., Welker, N. E. \& Papoutsakis, E. T. (1999a). Metabolic flux analysis elucidates the importance of acid-formation pathways in regulating solvent production by Clostridium acetobutylicum. Metab Eng 1, 206-213.

Desai, R. P., Nielsen, L. K. \& Papoutsakis, E. T. (1999b). Metabolic flux analysis elucidates the importance of acid-formation pathways in regulating solvent production by Clostridium acetobutylicum fermentations with non-linear constraints. J Biotechnol 71, 191-205.

Desvaux, M., Guedon, E. \& Petitdemange, H. (2000). Cellulose catabolism by Clostridium cellulolyticum growing in batch culture on defined medium. Appl Environ Microbiol 66, 2461-2470.

Desvaux, M., Guedon, E. \& Petitdemange, H. (2001). Carbon flux distribution and kinetics of cellulose fermentation in steady-state continuous cultures of Clostridium cellulolyticum on a chemically defined medium. J Bacteriol 183, 119-130.

Duong, T. V. C., Johnson, E. A. \& Demain, A. L. (1983). Thermophilic, anaerobic and cellulolytic bacteria. In Topics in Enzyme and Fermentation Biotechnology, pp. 156-195. Edited by A. Weisman. New York: Wiley.

Fields, M. W. \& Russell, J. B. (2000). Fibrobacter succinogenes S85 ferments ball-milled cellulose as fast as cellobiose until cellulose surface area is limiting. Appl Microbiol Biotechnol 54, 570-574.

Gelhaye, E., Gehin, A. \& Petitdemange, H. (1993a). Colonization of crystalline cellulose by Clostridium cellulolyticum ATCC 35319. Appl Environ Microbiol 59, 3154-3156.

Gelhaye, E., Petitdemange, H. \& Gay, R. (1993b). Adhesion and growth rate of Clostridium cellulolyticum ATCC 35319 on crystalline cellulose. J Bacteriol 175, 3452-3458.

Giallo, J., Gaudin, C., Belaich, J. P., Petitdemange, E. \& CailletMangin, F. (1983). Metabolism of glucose and cellobiose by cellulolytic mesophilic Clostridium sp. strain H10. Appl Environ Microbiol 45, 843-849.

Giallo, J., Gaudin, C. \& Belaich, J. P. (1985). Metabolism and solubilization of cellulose by Clostridium cellulolyticum H10. Appl Environ Microbiol 49, 1216-1221.

Goodwin, S. \& Zeikus, J. G. (1987). Ecophysiological adaptations of anaerobic bacteria to low $\mathrm{pH}$ : analysis of anaerobic digestion in acidic bog sediments. Appl Environ Microbiol 53, 57-64.

Guedon, E., Desvaux, M., Payot, S. \& Petitdemange, H. (1999a). Growth inhibition of Clostridium cellulolyticum by an inefficiently regulated carbon flow. Microbiology 145, 1831-1838.

Guedon, E., Payot, S., Desvaux, M. \& Petitdemange, H. (1999b). Carbon and electron flow in Clostridium cellulolyticum grown in chemostat culture on synthetic medium. J Bacteriol 181, 3262-3269.

Guedon, E., Desvaux, M. \& Petitdemange, H. (2000a). Kinetic analysis of Clostridium cellulolyticum carbohydrate metabolism: importance of glucose 1-phosphate and glucose 6-phosphate branch points for distribution of carbon fluxes inside and outside cells as revealed by steady-state continuous culture. J Bacteriol 182, 2010-2017.

Guedon, E., Payot, S., Desvaux, M. \& Petitdemange, H. (2000b). Relationships between cellobiose catabolism, enzyme levels and metabolic intermediates in Clostridium cellulolyticum grown in a synthetic medium. Biotechnol Bioeng 67, 327-335.

Holms, H. (1986). The central metabolic pathways of Escherichia coli: relationship between flux and control at a branch point, 
efficiency of conversion to biomass, and excretion of acetate. Curr Top Cell Regul 28, 69-105.

Holms, H. (1996). Flux analysis and control of the central metabolic pathways in Escherichia coli. FEMS Microbiol Rev 19, 85-116.

Huang, L., Gibbins, L. N. \& Forsberg, C. W. (1985). Transmembrane $\mathrm{pH}$ gradient and membrane potential in Clostridium acetobutylicum during growth under acetogenic and solventogenic conditions. Appl Environ Microbiol 50, 1043-1047.

Kalachniuk, H. I., Marounek, M., Kalachniuk, L. H. \& Savka, O. H. (1994). Rumen bacterial metabolism as affected by extracellular redox potential. Ukr Biokhim Zh 66, 30-40.

Kovárová-Kovar, K. \& Egli, T. (1998). Growth kinetics of suspended microbial cells: from single-substrate-controlled growth to mixed-substrate kinetics. Microbiol Mol Biol Rev 62, 646-666.

Kuznetsov, S. I., Dubinina, G. A. \& Lapteva, N. A. (1979). Biology of oligotrophic bacteria. Annu Rev Microbiol 33, 377-387.

Leschine, S. B. (1995). Cellulose degradation in anaerobic environments. Annu Rev Microbiol 8, 237-299.

Ljungdahl, L. G. \& Eriksson, K. E. (1985). Ecology of microbial cellulose degradation. Adv Microb Ecol 8, 237-299.

Mitchell, W. J. (1998). Physiology of carbohydrate to solvent conversion by clostridia. Adv Microb Physiol 39, 31-130.

Miyagi, A., Ohta, H., Kodama, T., Fukui, K., Kato, K. \& Shimono, T. (1994). Metabolic and energetic aspects of the growth response of Streptococcus rattus to environmental acidification in anaerobic continuous culture. Microbiology 140, 1945-1952.

Mokrasch, L. C. (1967). Use of 2,4,6-trinitrobenzenesulfonic acid for the coestimation of amines, amino acids, and proteins in mixtures. Anal Biochem 18, 64-71.

O'Sullivan, E. \& Condon, S. (1999). Relationship between acid tolerance, cytoplasmic $\mathrm{pH}$, and ATP and $\mathrm{H}^{+}$-ATPase levels in chemostat cultures of Lactococcus lactis. Appl Environ Microbiol 65, 2287-2293.

Papoutsakis, E. T. (1984). Equations and calculations for fermentations of butyric acid bacteria. Biotechnol Bioeng 26, 174-187.

Payot, S., Guedon, E., Cailliez, C., Gelhaye, E. \& Petitdemange, H. (1998). Metabolism of cellobiose by Clostridium cellulolyticum growing in continuous culture: evidence for decreased NADH reoxidation as a factor limiting growth. Microbiology 144, 375-384.

Petitdemange, E., Caillet, F., Giallo, J. \& Gaudin, C. (1984). Clostridium cellulolyticum sp. nov., a cellulolytic mesophilic species from decayed grass. Int J Syst Bacteriol 34, 155-159.

Russell, J. B. \& Diez-Gonzalez, F. (1998). The effects of fermentation acids on bacterial growth. Adv Microb Physiol 39, 205-234.

Russell, J. B. \& Dombrowski, D. B. (1980). Effect of $\mathrm{pH}$ on the efficiency of growth by pure cultures of rumen bacteria in continuous culture. Appl Environ Microbiol 39, 604-610.

Russell, J. B. \& Wilson, D. B. (1996). Why are ruminal cellulolytic bacteria unable to digest cellulose at low pH? J Dairy Sci 79, 1503-1509.

Russell, J. B., Bond, D. R. \& Cook, G. M. (1996). The fructose diphosphate/phosphate regulation of carbohydrate metabolism in low G + C Gram positive anaerobes. Res Microbiol 147, 528-534.

Stewart, C. S. (1977). Factors affecting the cellulolytic activity of rumen contents. Appl Environ Microbiol 33, 497-502.

Tomme, P., Warren, R. A. J. \& Gilkes, N. R. (1995). Cellulose hydrolysis by bacteria and fungi. Adv Microb Physiol 37, 1-81.

Weimer, P. J., Lopez-Guisa, J. M. \& French, A. D. (1990). Effect of cellulose fine structure on kinetics of its digestion by mixed ruminal microorganisms in vitro. Appl Environ Microbiol 56, 2421-2429.

Weimer, P. J., French, A. D. \& Calamari, T. A. (1991a). Differential fermentation of cellulose allomorphs by ruminal cellulolytic bacteria. Appl Environ Microbiol 57, 3101-3106.

Weimer, P. J., Shi, Y. \& Odt, C. L. (1991b). A segmented gas/liquid delivery system for continuous culture of microorganisms on insoluble substrates and its use for growth of Ruminococcus flavefaciens on cellulose. Appl Microbiol Biotechnol 36, 178-183.

Wolin, M. J. \& Miller, T. L. (1987). Bioconversion of organic carbon to $\mathrm{CH}_{4}$ and $\mathrm{CO}_{2}$. Geomicrobiol J 5, 239-259.

Received 6 November 2000; revised 29 January 2001; accepted 12 February 2001. 